\title{
DEVELOPMENT AND ENHANCEMENT OF INCLUSION SERVICES AT HIGHER EDUCATION LEVEL
}

\author{
Irene Josa ${ }^{1}$, Carles Farré1, Imma Gálvez-Carrillo', Didac Ferrer-Balas', Montserrat \\ Vilalta ${ }^{1}$, Lídia Montero ${ }^{1}$ \\ ${ }^{1}$ Universitat Politècnica de Catalunya (Spain)
}

\begin{abstract}
Everyone is unique in their own way and it is necessary to embrace this diversity and make positive use of it. At all levels of education, differences between students can provide a good learning opportunity since every student will have different skills and ways of approaching the same problem. Therefore, universities need to offer education services that are conducive to learning, suitable and inclusive for each student. This will not only improve the education process of students with special needs but also lead to an improved service to all the involved stakeholders, such as professors and administrative personnel. Moreover, this can create a learning environment that favours the development of values such as respect and tolerance of diversity.

Grounded in this philosophy of inclusive education, the Government Board of the Universitat Politècnica de Catalunya (UPC) approved in 2016 its first Inclusion Plan for the period 2017-2020. More recently, the Government Board of the UPC prompted the creation of an ad-hoc Task Group (TG) to analyse and improve the existing inclusion services and/or design new ones using service design methodology. The TG was made up of volunteers from the UPC community, consisting of 10 students, 10 academic staff, and 10 administrative staff. They were assisted and guided by professional experts in service design. This paper reports the activities and results of the TG.
\end{abstract}

The main focus of the TG was the planning, design, and development of inclusion services in higher education. These services aim at supporting the inclusion of students with physical disabilities, learning disabilities as well as any other special education needs (D/SN).

The TG conducted a systematic process, based on service design methodology, which consisted of four broad phases. In the first phase, the TG carried out research into the experience, values, and practices of all the groups involved. This research was qualitative and based on several unstructured interviews of students, professors, faculty directors, students' advisors, and administrative staff. A total of 14 students with special needs, 17 academic staff, and 13 administrative staff were interviewed. In the second phase, the interviews were analysed through four different models: user journey, stakeholders map, gaps map, and service plan. Such models are useful in order to identify and classify the possible opportunities for improvement. Furthermore, these models were presented and validated in a public meeting that was open to the whole UPC community, with a total of around 60 attendees. In the third phase, the most interesting and significant opportunities for improvement were chosen and prototypes for them were developed. The five projects that were selected for prototyping belong to the following areas: 1 ) information about inclusion services given to students when they enrol; 2) adaptation of examination procedures; 3 ) training of lecturers to assist students with disabilities or special needs; 4) information system with individualised data for students with disabilities or special needs; and 5) general academic regulations about inclusion. The last phase is iterative and involves modifying the prototypes until the service is optimum.

The outcomes of this process are expected to be implemented at UPC during the 2019-20 academic year.

Keywords: inclusion, disabilities, special education needs, higher education

\section{INTRODUCTION}

Everyone is unique in their own way and it is necessary to embrace this diversity and make positive use of it. At all levels of education, differences between students can provide a good learning opportunity since every student will have different skills and ways of approaching the same problem. Therefore, universities 
need to offer education services that are conducive to learning, suitable and inclusive for each student. This will not only improve the education process of students with special needs but also lead to an improved service to all the involved stakeholders, such as professors and administrative personnel. Moreover, this can create a learning environment that favours the development of values such as respect and tolerance of diversity.

Grounded in this philosophy of inclusive education, the Government Board of the Universitat Politècnica de Catalunya (UPC) approved in 2016 its first Inclusion Plan for the period 2017-2020 [1]. More recently, the same board prompted the creation of an ad-hoc collaborative Task Group (TG) to analyse and improve the existing inclusion services and/or design new ones using service design methodology. The TG was made up of volunteers from the UPC community, consisting of 10 students, 10 academic staff, and 10 administrative staff. They were assisted and guided by professional experts in service design. This paper reports the activities and results of the TG.

The main focus of the TG was the planning, design, and development of inclusion services in higher education. These services aim at supporting the inclusion of students with physical disabilities, learning disabilities as well as any other special education needs (D/SN). The number of students with a certified disability that used the inclusion services has evolved from 100 to 160 in the period 2008-2018. However, it has to be noticed that the number of students with special needs is growing much faster, and -though no reliable data are available yet- they are becoming the main concern to all people related to delivering the inclusion services. Therefore, this project aims at improving the inclusion services and allowing scaling them up in terms of user in the next years.

The TG conducted a systematic process, based on service design methodology $[2,3,4,5]$. This methodology has previously been applied mainly in the field of public policies $[6,7,8,9,10]$. Other aspects that have been considered for the development of the process can be found in $[11,12,13,14,15]$.

The process carried out consisted of four broad phases. In the first phase, the TG carried out research into the experience, values, and practices of all the groups involved. This research was qualitative and based on several unstructured interviews of students, professors, faculty directors, students' advisors, and administrative staff. A total of 14 students with special needs, 17 academic staff, and 13 administrative staff were interviewed. In the second phase, the interviews were analysed through four different models: user journey, stakeholders map, gaps map, and service plan. Such models are useful in order to identify and classify the possible opportunities for improvement. Furthermore, these models were presented and evaluated at a public meeting that was open to the whole UPC community, with a total of around 60 attendees. In the third phase, the most interesting and significant opportunities for improvement were chosen and prototypes for them were developed. The five projects that were selected for prototyping belong to the following areas: 1) information about inclusion services given to students when they enrol; 2) adaptation of examination procedures; 3 ) training of lecturers to assist students with disabilities or special needs; 4 ) information system with individualised data for students with disabilities or special needs; and 5) general academic regulations about inclusion. The last phase is iterative and involves modifying the prototypes until the service is optimum.

The outcomes of this process are expected to be implemented at the UPC during the 2019-20 academic year. This has been an explicit commitment of the Governing Board, and has been considered as a fundamental element of motivation for the collaboration of the TG.

\section{METHODOLOGY}

\subsection{Introduction}

This section aims at overviewing the methodology that was followed in the design of the inclusion services. As was mentioned above, the process consisted of four phases, namely: initial research on the current state of implementation of the inclusion services; an in-depth analysis of the current status at university of the service; the choice and development of prototypes of the most interesting and significant opportunities for improvement; finally, the iteration and modification of the prototypes until an optimum service was achieved. This process is summarised in Figure 1. 


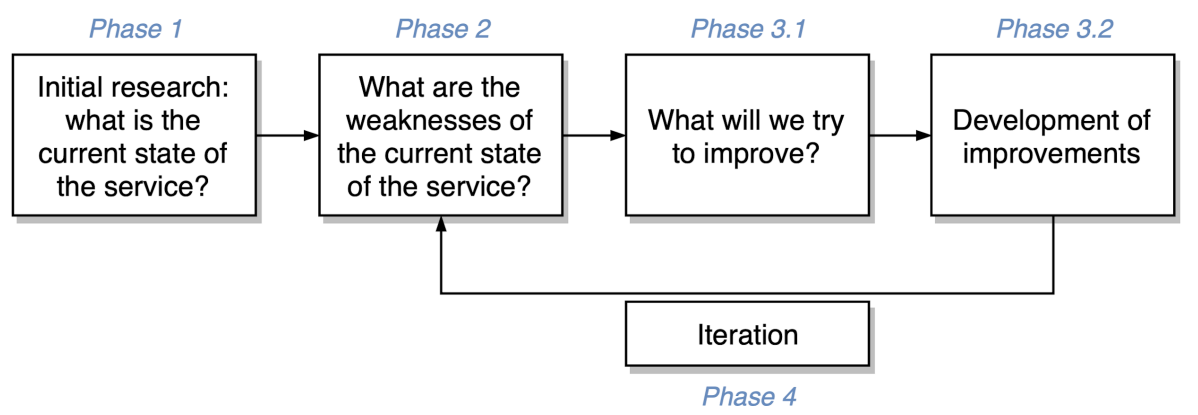

Figure 1 Diagram showing a summary of the developed process

\subsection{First phase: research on the current state}

In order to better understand the needs and shortcomings of the existing inclusion services at the university it is essential that first an analysis of the current state of the service is carried out. Even though the people directly involved in the administration and provision of this service might have useful information about it, it is important that all the stakeholders are taken into account.

According to [5], the validity of qualitative research can be proved through four different methods:

- Methodological triangulation: the results from different methodologies (interviews, observations, workshops, etc.) coincide.

- Source triangulation: the results obtained from different stakeholders coincide.

- Researcher triangulation: the results obtained by different researchers coincide and are, therefore, not biased by their perceptions.

- Saturation: research is carried out until no more new observations are found.

Therefore, interviews were carried out in order to obtain information on factors such as: motivation, barriers, experience, habits, opportunities, difficulties, shortcomings, etc. from all the stakeholders (students, professors, faculty directors, students' advisors, and administrative staff). The interviews were oral and semi-structured: its structure was initially broadly predefined but adaptable to the real interview's development. The initial structure was organised according to the following points: (1) opening, (2), general topics, (3) specific topics, (4) assurance, (5) closure.

The main groups of stakeholders identified were three: first of all, the students, who are the potential users of the service and who can give information on needs, experience of use, difficulties, etc.; secondly, academic staff and administrative personnel that are directly in touch with the students; thirdly, administrative personnel that are indirectly linked to the service. In the end, a total of 14 students with special needs, 17 professors, and 13 administrative staff were interviewed.

The outcomes of the interviews were organised as follows: on the one hand, each of the main ideas obtained from the conversations was summarised on a different post-it note; on the other hand, reflections and/or comments on the interviews were written down on post-it notes of a different colour than the previous ones.

\subsection{Second phase: analysis of the current state}

In the second phase, the interviews were analysed through four different models: user journey, stakeholders map, gaps map, and service plan. Such models are useful in order to identify and classify the possible opportunities for improvement. Furthermore, these models were presented and assessed at a public meeting that was open to the whole UPC community, with a total of around 60 attendees.

Before developing the models, an affinity map was built. The information gathered during the interviews was classified into four different groups: arrival at university, giving and receiving the service, adaptations, spaces and accessibility. After grouping all the information, it was further classified into subtopics. Table 1 shows a summary of the information that was collected at this stage. Also, Figure 6 in the Appendix shows the completed model. 
Table 1. Topics, subtopics and corresponding findings found during the analysis of the interviews

\begin{tabular}{|c|c|c|}
\hline Topic & Subtopic & Main findings and conclusions \\
\hline \multirow{5}{*}{$\begin{array}{l}\text { Arrival at } \\
\text { university }\end{array}$} & $\begin{array}{l}\text { University's } \\
\text { commitment }\end{array}$ & Not enough commitment \\
\hline & Dissemination & $\begin{array}{l}\text { Some people want or need more information; there is only } \\
\text { information at initial stages; it is difficult to find information } \\
\text { about the service }\end{array}$ \\
\hline & Process & $\begin{array}{l}\text { The process to reach the inclusion service is difficult and } \\
\text { long; the process depends on the faculty (it is not } \\
\text { homogeneous across the university) }\end{array}$ \\
\hline & Student's detection & $\begin{array}{l}\text { Professors don't know which students have special needs } \\
\text { (only the inclusion service does) and therefore make a } \\
\text { diagnosis by themselves }\end{array}$ \\
\hline & $\begin{array}{l}\text { Student's first } \\
\text { experience }\end{array}$ & $\begin{array}{l}\text { Students that have been supported by the service are } \\
\text { satisfied by it. However, not all of them find out about the } \\
\text { service }\end{array}$ \\
\hline \multirow{6}{*}{$\begin{array}{l}\text { Giving and } \\
\text { receiving the } \\
\text { service }\end{array}$} & Detection & $\begin{array}{l}\text { It is necessary to analyse the detected cases and include } \\
\text { them in the system; it is necessary to analyse the most } \\
\text { serious cases and analyse their feasibility }\end{array}$ \\
\hline & Tutor & $\begin{array}{l}\text { Students lack advice for their studies; academic staff spend } \\
\text { a lot of extra hours with the students with special needs; } \\
\text { having a tutor is well received among the students; not all the } \\
\text { students have a tutor }\end{array}$ \\
\hline & Information & $\begin{array}{l}\text { There is poor internal communication at UPC; students feel } \\
\text { they wish the service was better disseminated; professors } \\
\text { also feel that they lack information }\end{array}$ \\
\hline & Support to students & $\begin{array}{l}\text { More scholarships; meetings between students with the } \\
\text { same problems }\end{array}$ \\
\hline & Training & $\begin{array}{l}\text { Lack of training for professors and administrative staff; } \\
\text { training strategies are needed; community awareness is } \\
\text { needed }\end{array}$ \\
\hline & Work dynamics & $\begin{array}{l}\text { It is necessary to deal with inclusion institutionally; more } \\
\text { proactivity from professors is needed; the tasks that directors } \\
\text { perform should be specified; there is no established protocol }\end{array}$ \\
\hline \multirow[b]{3}{*}{ Adaptations } & Academic level & $\begin{array}{l}\text { The required knowledge level should not be reduced; the } \\
\text { levels of preparation of all the students are very different }\end{array}$ \\
\hline & Exams & $\begin{array}{l}\text { There is a need for changing the format of exams; students } \\
\text { with special needs are given more time in the exams }\end{array}$ \\
\hline & Regulations & $\begin{array}{l}\text { It is necessary to clarify and review the regulation to see how } \\
\text { to improve; it is necessary to acknowledge inclusion in the } \\
\text { assessment processes of students, academic and } \\
\text { administrative staff; the existing regulation is basically for } \\
\text { academic and administrative staff }\end{array}$ \\
\hline \multirow{3}{*}{$\begin{array}{l}\text { Spaces and } \\
\text { accessibility }\end{array}$} & Classrooms & $\begin{array}{l}\text { People in charge of the assignation of rooms for classes are } \\
\text { janitors, who don't perceive the different needs of different } \\
\text { students; it seems that there is a lack of resources; lifts and } \\
\text { ramps are essential }\end{array}$ \\
\hline & $\begin{array}{l}\text { Specific needs in } \\
\text { the classrooms }\end{array}$ & $\begin{array}{l}\text { Tables should be adapted if necessary, maybe it is } \\
\text { necessary to provide special computers, it is necessary to } \\
\text { give more time during exams }\end{array}$ \\
\hline & $\begin{array}{l}\text { Learning } \\
\text { environment }\end{array}$ & $\begin{array}{l}\text { Some students wish there was more silence and fewer } \\
\text { distractions during the exams }\end{array}$ \\
\hline
\end{tabular}




\subsubsection{User Journey}

This model offers a visualisation of the experience of one or more users with the experience being analysed. The visualisation orders chronologically the user's actions. For each of the stages, it shows the user's overall experience and those places in which he or she is in touch with the inclusion service. Also, Figure A. 1 shows the completed model.

Table 2. Factors considered in the development of a User Journey Model

\begin{tabular}{|l|l|}
\hline $\begin{array}{l}\text { Information to } \\
\text { be filled }\end{array}$ & Description \\
\hline Stage & The different stages of the student at university are described. \\
\hline Emotional curve & $\begin{array}{l}\text { The user's experience at each of the stages is described. For } \\
\text { example: insecurity, satisfaction, etc. }\end{array}$ \\
\hline Interaction points & $\begin{array}{l}\text { The different interaction points of the student with different people } \\
\text { and individuals is described (Face-to-face, digital, printed, } \\
\text { product, space, etc.). }\end{array}$ \\
\hline Inclusion level & $\begin{array}{l}\text { For each stage, it is decided whether there is inclusion, integration } \\
\text { or exclusion. Ideally, there should be inclusion at all stages. }\end{array}$ \\
\hline Influences & $\begin{array}{l}\text { The different influences that might affect the student are recorded; } \\
\text { for example, about the expectations of the service he or she will } \\
\text { receive. }\end{array}$ \\
\hline Discoveries & Conclusions on the overall information are drawn. \\
\hline
\end{tabular}

\subsubsection{Service Plan}

This model also offers a visualisation of the different processes involved in the inclusion service but, in contrast to the user journey model, it is not only focused on the user but also on other stakeholders. Also, Figure A.2 shows the completed model.

Table 3. Factors considered in the development of a Service Plan Model

\begin{tabular}{|l|l|}
\hline $\begin{array}{l}\text { Information to be } \\
\text { filled }\end{array}$ & Description \\
\hline Stage & The different stages of the student at university are described. \\
\hline $\begin{array}{l}\text { "Visible" } \\
\text { interaction points }\end{array}$ & $\begin{array}{l}\text { The direct interactions that the student has with administrative staff, } \\
\text { professors or any physical material are described. }\end{array}$ \\
\hline $\begin{array}{l}\text { "Invisible" } \\
\text { interactions }\end{array}$ & $\begin{array}{l}\text { The indirect interactions that happen are described. For example, } \\
\text { a lecturer's preparation for a class is something that will indirectly } \\
\text { be seen by the student. }\end{array}$ \\
\hline Inclusion level & $\begin{array}{l}\text { For each of the stages, it is decided whether there is inclusion, } \\
\text { integration or exclusion. Ideally, there should be inclusion at all } \\
\text { stages. }\end{array}$ \\
\hline Discoveries & Conclusions on the overall information are drawn. \\
\hline
\end{tabular}

\subsubsection{Gaps Model}

The Gaps Model is a model whose main objective is to identify the weaknesses in the quality of service by analysing the shortcomings in different areas. From the model, four different gaps in the service can be found:

- Gap 1: shortcomings that appear when an organisation cannot capture the expectations and needs of the users.

- Gap 2: shortcomings that appear when an organisation can capture well the users' expectations and needs, but is not able to design a service accordingly.

- Gap 3: shortcomings that appear when, even though the design is adequate, the people giving the service are actually not following the standards set for its correct development. 
- Gap 4: shortcomings that appear when communications about the service transmit an image that does not adequately reflect to the real quality of service.

Each of these is shown graphically in Figure A.3.

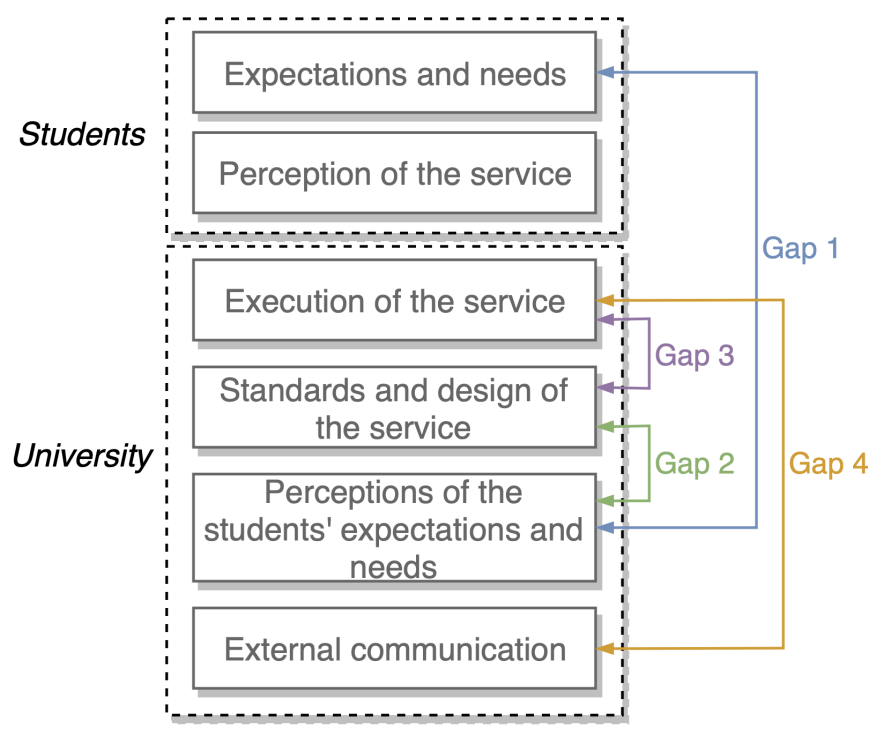

Figure 2. Diagram showing the gaps that can be analysed with the Gaps Model

Figure 8 in the Appendix shows the completed model.

\subsection{Third Phase: choice and development of opportunities for improvement}

The main goal of this phase was to identify, select and define the most interesting and significant opportunities for improvement.

\subsubsection{Identification of candidate action areas}

First, the TG collected and clustered the comments and suggestions that the participants in the open session made on the three different models developed in the previous phase (user journey, gaps map, and service plan). The clusters were labeled accordingly to identify the candidate focus areas of interest.

\subsubsection{Selection of action areas.}

The candidate focus areas were ranked and each TG member chose one in which s/he wanted to work. In this way, five different teams were formed, each of them focused on one of these five action areas: 1) Information and publicity, 2) Learning materials and methodologies, 3) Training of lecturers, 4) Information Systems and 5) Protocols and regulations. See Figure 3 for an example of the procedure.

\subsubsection{Idea formulation}

Each team worked separately in its action area. Ideas and opportunities for improvement were formulated and discussed. Each team produced a list of ideas within the scope of its action area. The ideas were ranked according to five criteria: Joint responsibility (i.e. the idea empowers the students), Confidentially (i.e. no sensitive data is disclosed without explicit authorisation), Quality (i.e. the idea responds to actual needs and expectations), Feasibility (i.e. the idea can be implemented with the available resources), and Novelty (i.e. the idea is original and nothing similar has ever tried before). The most ranked idea in each team is then selected for further development (Table 4). In section 3, each of the chosen ideas is described in more detail. 


\subsubsection{Prototyping}

Each team developed a prototype of its idea to present and discussed it with the other teams. Cardboard prototypes were made to illustrate the main points. A further elaboration consisted of staged simulations of the solution to be implemented. The feedback gathered from the other teams were then applied to refine the prototypes for the following phase. An example is shown in Figure 4.

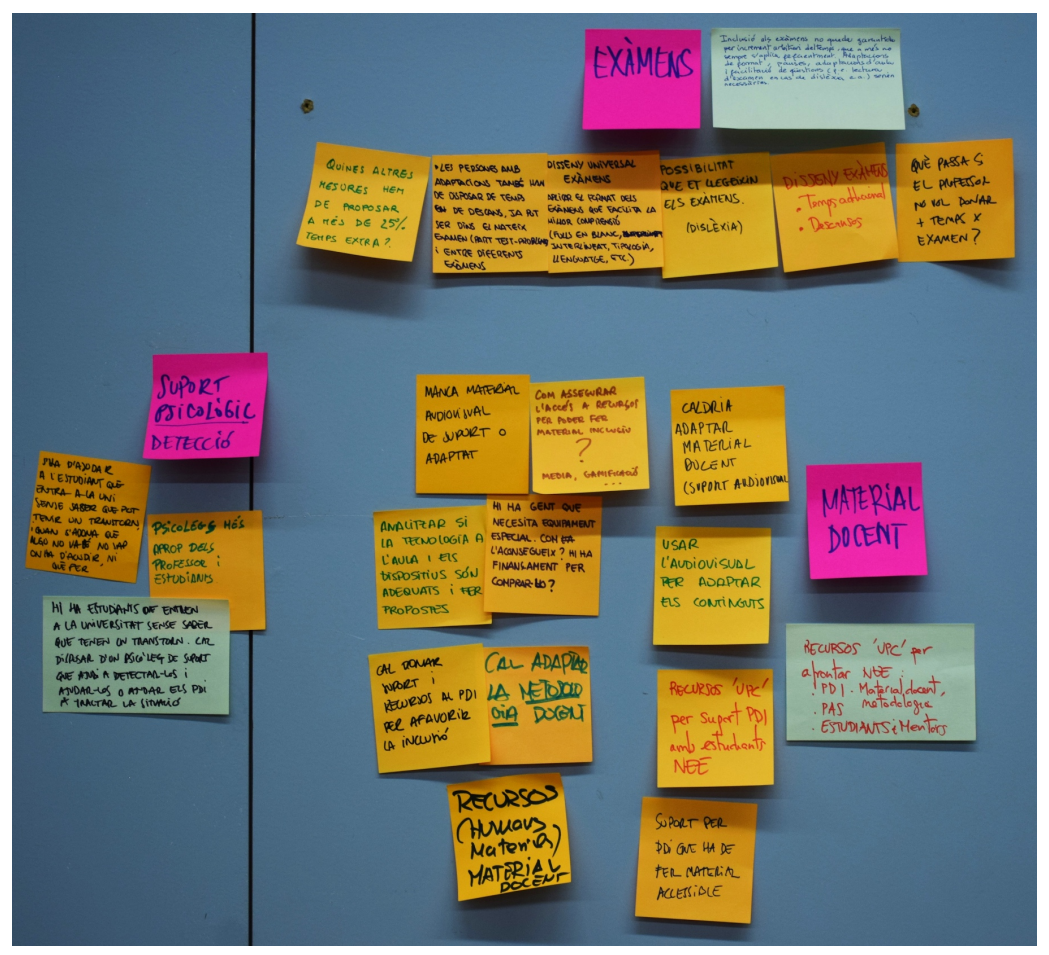

Figure 3. Comments (yellow post-its) clustered in candidate areas (labelled with pink post-its)

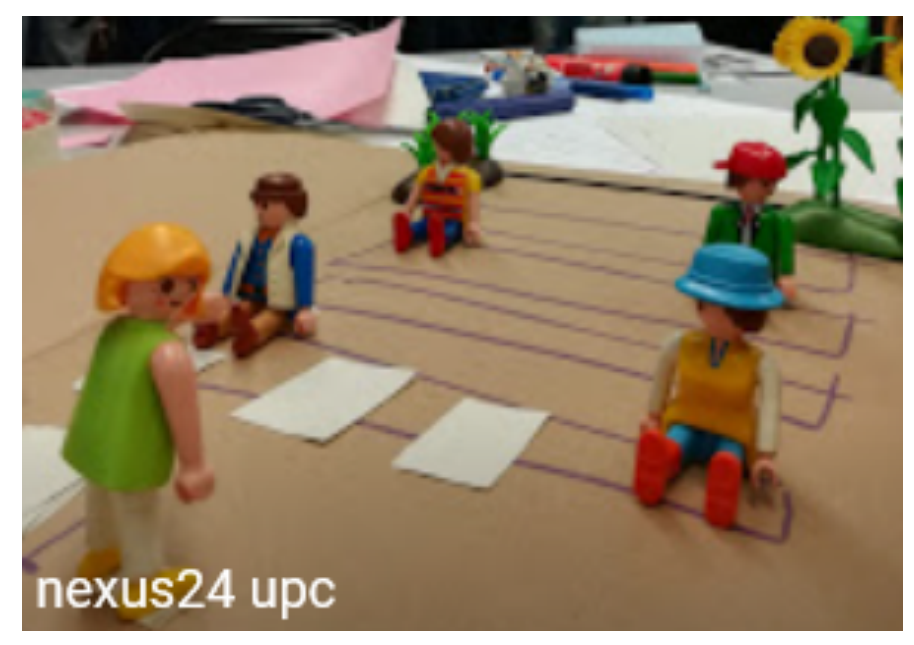

Figure 4. Cardboard prototype for project P2 (see Table 6) 
Table 4. Ranking of ideas for an action area

\begin{tabular}{|c|c|c|c|c|c|c|}
\hline Idea & 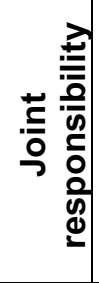 & 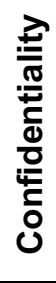 & $\frac{\overrightarrow{7}}{\frac{7}{\sigma}}$ & 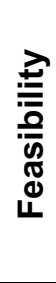 & $\begin{array}{l}\frac{7}{0} \\
\frac{0}{0} \\
\mathbf{z}\end{array}$ & 胥 \\
\hline $\begin{array}{l}\text { Meetings at the beginning of the semester with those } \\
\text { professors that will have students with SEN to get } \\
\text { information, resources, etc. }\end{array}$ & 5 & 4 & 5 & 5 & 5 & 24 \\
\hline $\begin{array}{l}\text { Meetings in the end of the year with those professors that will } \\
\text { have students with SEN, to share experiences }\end{array}$ & 5 & 4 & 5 & 5 & 5 & 24 \\
\hline Device (app, chat, online group, etc.) on inclusion & 3 & 3 & 5 & 3 & 5 & 19 \\
\hline $\begin{array}{l}\text { Leisure activities (cultural week, competitions, hackathons, } \\
\text { etc.) to raise awareness }\end{array}$ & 3 & 5 & 4 & 3 & 5 & 20 \\
\hline Awareness campaign: "Be nice" & 2 & 5 & 3 & 3 & 5 & 18 \\
\hline $\begin{array}{l}\text { Experience exchange with other universities, both national } \\
\text { and international }\end{array}$ & 2 & 5 & 5 & 4 & 3 & 19 \\
\hline Courses: online, MOOCs, etc. & 3 & 5 & 3 & 4 & 1 & 16 \\
\hline Bibliographic resources: manuals, books, websites, etc. & 1 & 5 & 3 & 4 & 1 & 14 \\
\hline
\end{tabular}

\subsection{Fourth phase: first iteration}

The different prototypes were shown to external people, as is explained in the next section. With this new feedback, the prototypes were refined and the five teams of the TG concluded their work. For each prototype, a complete description was produced: the problem/need that it addresses, the required inputs and resources, the activities that it involves, the outputs that it produces, and the expected outcomes (benefits), and some guidelines (implementation requirements) for the next iterations.

\section{RESULTS}

In this section, we describe the 5 projects that were developed by the TG to improve the inclusion services in the UPC.

Table 5. Characteristics of the first developed project (P1)

\begin{tabular}{|l|l|}
\hline P1: Meet-Inc: support for lecturers that have students with special educational needs (SEN) \\
\hline Improvement goal & $\begin{array}{l}\text { To increase the inclusion-awareness of the teaching staff with respect to their } \\
\text { students with SEN, before the start of the classes. }\end{array}$ \\
\hline Description & $\begin{array}{l}\text { Each academic centre of the UPC has an inclusion manager that will } \\
\text { convene two meetings, at the beginning and at the end of the course, with } \\
\text { the lecturers involved (together with some administrative staff and student } \\
\text { representatives): to inform about the students with SEN and receive input } \\
\text { from the lecturers. }\end{array}$ \\
\hline Prototype & $\begin{array}{l}\text { An actual meeting with lecturers in UPC's Terrassa Campus was held. A total } \\
\text { of 50 people attended, of which 22 provided very positive feedback via an } \\
\text { online survey. }\end{array}$ \\
\hline $\begin{array}{l}\text { Implementation } \\
\text { requirements }\end{array}$ & $\begin{array}{l}\text { All the inclusion managers in the UPC should conduct the Meet -Inc in } \\
\text { their academic centres. } \\
\text { Information about students with SEN needs to be collected and } \\
\text { distributed to the inclusion managers. }\end{array}$ \\
\hline
\end{tabular}


Table 6. Characteristics of the second developed project (P2)

\begin{tabular}{|l|l|}
\hline Inclusion protocol for assessment tests (exams adaptations) \\
\hline Improvement goal & $\begin{array}{l}\text { To increase 1) the inclusiveness of the assessment tests; 2) the knowledge of } \\
\text { the norm that regulates the tests; and 3) its effective compliance. }\end{array}$ \\
\hline Description & $\begin{array}{l}\text { A new protocol needs to be elaborated to better inform the lecturers about the } \\
\text { required actions before and during the evaluation tests of students with SEN. }\end{array}$ \\
\hline Prototype & A first draft of the inclusion protocol document for the evaluation tests. \\
\hline $\begin{array}{l}\text { Implementation } \\
\text { requirements }\end{array}$ & $\begin{array}{l}\text { Make the draft known to all the people involved (inclusion managers, } \\
\text { lecturers, etc.) in all academic centres. } \\
\text { Conduct a pilot test during the course 2019-2020 in } 2 \text { academic centres } \\
\text { to refine the draft. }\end{array}$ \\
\hline
\end{tabular}

Table 7. Characteristics of the third developed project $(P 3)$

\begin{tabular}{|l|l|}
\hline \multicolumn{2}{|l|}{ Regulations: NAGRAMA } \\
\hline Improvement goal & $\begin{array}{l}\text { To normalize the situation (not just inform) in all the circumstances and } \\
\text { procedures in which a student with SEN participates in the university life: } \\
\text { enrollment, class attendance, examinations, etc. To guarantee equal } \\
\text { opportunities to the entire community. }\end{array}$ \\
\hline Description & $\begin{array}{l}\text { The existing regulation and action protocols still not adequately regulate the } \\
\text { situation for which students with SEN. }\end{array}$ \\
\hline Prototype & $\begin{array}{l}\text { A draft which includes the proposed curricular adaptations defined by the } \\
\text { Conference of Presidents of Spanish Universities. }\end{array}$ \\
\hline $\begin{array}{l}\text { Implementation } \\
\text { requirements }\end{array}$ & $\bullet \quad$ New inclusion elements to add to the regulations. \\
\hline
\end{tabular}

Table 8. Characteristics of the fourth developed project (P4)

\begin{tabular}{|l|l|}
\hline Information prior to enrollment \\
\hline Improvement goal & $\begin{array}{l}\text { To provide better information to the students during their first enrollment so } \\
\text { that they have all the required information about all the inclusion services in } \\
\text { the UPC from the very beginning. }\end{array}$ \\
\hline Description & The students will get more information about SEN before starting university. \\
\hline Prototype & $\begin{array}{l}\text { A draft that shows where the information should be located and how it should } \\
\text { be presented in the online system that the students use to perform } \\
\text { administrative procedures (e-secretary) }\end{array}$ \\
\hline $\begin{array}{l}\text { Implementation } \\
\text { requirements }\end{array}$ & $\begin{array}{l}\text { Train informants to assist students with SEN during the enrollment } \\
\text { process. }\end{array}$ \\
\hline
\end{tabular}

Table 9. Characteristics of the fifth developed project (P5)

\begin{tabular}{|c|c|}
\hline \multicolumn{2}{|c|}{ Information system and management of the UPC Inclusion Services } \\
\hline Improvement goal & $\begin{array}{l}\text { To improve the coordination of the students with SEN with the agents } \\
\text { involved in the inclusion services. }\end{array}$ \\
\hline Description & $\begin{array}{l}\text { The different inclusion services offered in the UPC must be standardized and } \\
\text { connected. The information gathering process must be centralized. Each } \\
\text { student attended by the inclusion services must have a unique record that } \\
\text { should be accessible by the inclusion managers and the authorized people. }\end{array}$ \\
\hline Prototype & An online prototype to gather data from students with SEN \\
\hline $\begin{array}{l}\text { Implementation } \\
\text { requirements }\end{array}$ & $\begin{array}{l}\text { - An online system through which the students can send the information } \\
\text { and the supporting documentation, together with their explicit consent to } \\
\text { be attended by the inclusion services. } \\
\text { - Training of the agents involved on the use of the system. } \\
\text { - Pilot trial at } 2 \text { centers of the UPC to refine the system. }\end{array}$ \\
\hline
\end{tabular}




\section{CONCLUSIONS}

After having described all the process involved in the design of the inclusion service at UPC, we can conclude with the following remarks:

- Generally, there are not many established methodologies for the development of this kind of services. Moreover, the process and tools for making university more inclusive are still not well studied. Even though there are exceptions, there is an international lack of formal procedures to make universities a more adequate environment for students with SEN.

- The methodology used requires many group meetings and field work; however, it is useful when aiming at designing a service that will solve its current shortcomings and be able to find the best opportunities for improvement.

- Many opportunities for improvement where found during the process, but in the end it was necessary to limit the amount of projects to five. In order to choose them, each project was scored with reference to five characteristics: joint responsibility, confidentially, quality, feasibility, and novelty.

\section{ACKNOWLEDGEMENTS}

We would like to show gratitude to "We question our project", for assistance with the development of the development methodology. Besides, we would also like to thank Carme Alcalà, Juli Boned, Sergi Bladé, Jasmina Casals, Lina Chalé, M. Carme Estrada, Alba Fernández, Daniel Guash, Carme Hervada, Sofia Pascual, Pere Riu, Pablo Nicolás Oshiro, Lucía Fernández, Carme Góngora, Kirian Garcia, Emi Papiol as well as the Association of Industrial Engineering Students. All of them provided valuable insight during the whole process, as well as support carrying out the interviews and developing the prototypes.

\section{REFERENCES}

[1] Universitat Politècnica de Catalunya, "Pla d'inclusió UPC 2017-20", Sessió 4 del Consell de Govern, 2017. Retrieved from URL: https://govern.upc.edu/ca/consell-de-govern/consell-de-govern/sessio-4-2017de-consell-de-govern/11/apovacio-del-pla-dinclusio-de-la-upc-2017-2020/11-13-pla-inclusio-upc-201720.pdf/@@isplay-file/visiblefile/

[2] Gray, D. and Vander Wal, T. The Connected Company. Sebastopol (EEUU): O'Reilly Media, 2012

[3] Kimbell, L. The Service Innovation Handbook. Action-oriented creative thinking toolkit for service organizations. Amsterdam: BIS, 2014.

[4] Meroni, A. and Sangiorgi, D. Design for services (Meroni, A. and Sangiorgi, D. Eds.) Aldershot: Gower Publishing, 2011.

[5] Stickdorn, Horness, Lawrence \& Schneider. This is Service Design Doing. Applying Service Design Thinking in the Real World. A practitioner's handbook. Sebastopol (EEUU): O'Reilly Media, 2017.

[6] Bason, C. Design for Policy. Oxford (RU): Routledge, 2014.

[7] Design Commission. Restarting Britain 2. Design and Public Services. Londres (RU): Policy Connect [8] Kimbell, L. Applying Design Approaches to Policy Making: Discovering Policy Lab. Brighton (RU): Universitat de Brighton, 2015.

[9] Mindlab. Co-production. Towards a new walfare model. Conpenhaguen (Dinamarca): Mindlab, 2013.

[10] Sharing Experience Europe. Design for Public Good. Londres (RU): Design Council, 2013.

[11] Kimbell, L., and Blomberg, J. "The object of service design" in Designing for service. Key issues and new directions (Sangiorgi, D. and Prendiville, A. Eds.), 81-94. London, UK: Bloomsbury, 2017.

[12] Grönroos \& Voima. "Critical Service Logic: Making Sense of Value Creation and Co-Creation". Journal of the Academy of Marketing Science, 41, 133-150. 2013.

[13] Wilson, Zeithaml, Bitner, \& Gremler. Services Marketing. Integrating Customer Focus Accross the Firm. Berkshire: McGraw-Hill Higher Education, 2012.

[14] Gummesson \& Lovelock. "Whither Services Marketing? In Search of a New Paradigm and Fresh Perspectives". Journal of Service Research, 7 (1), 20-41, 2004

[15] Vargo \& Lusch. "Evolving to a New Dominant Logic". Journal of Marketing, 68 (1), 1-17, 2004. 
APPENDIX

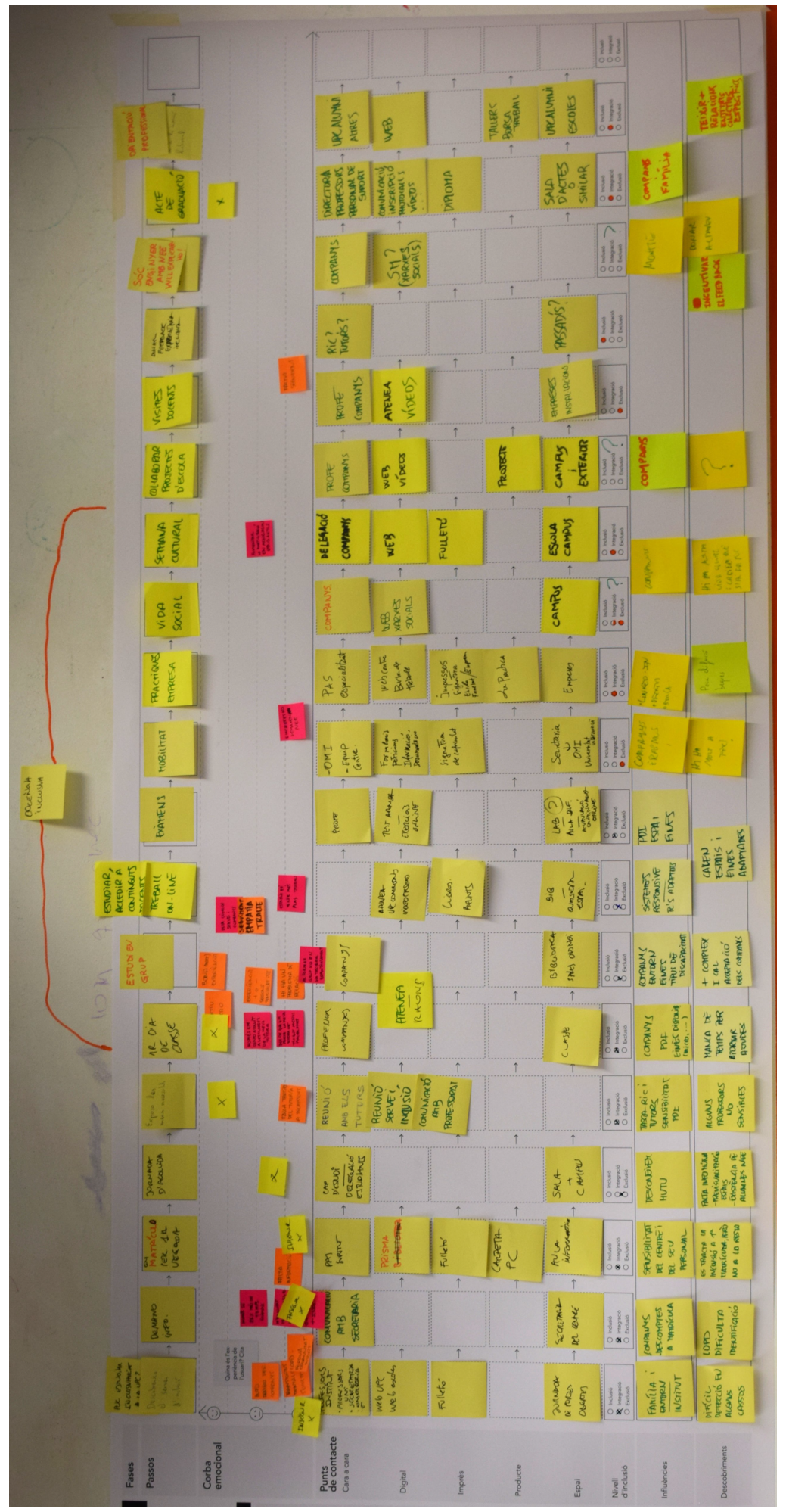

Figure A.1 Development of the User Journey Model 


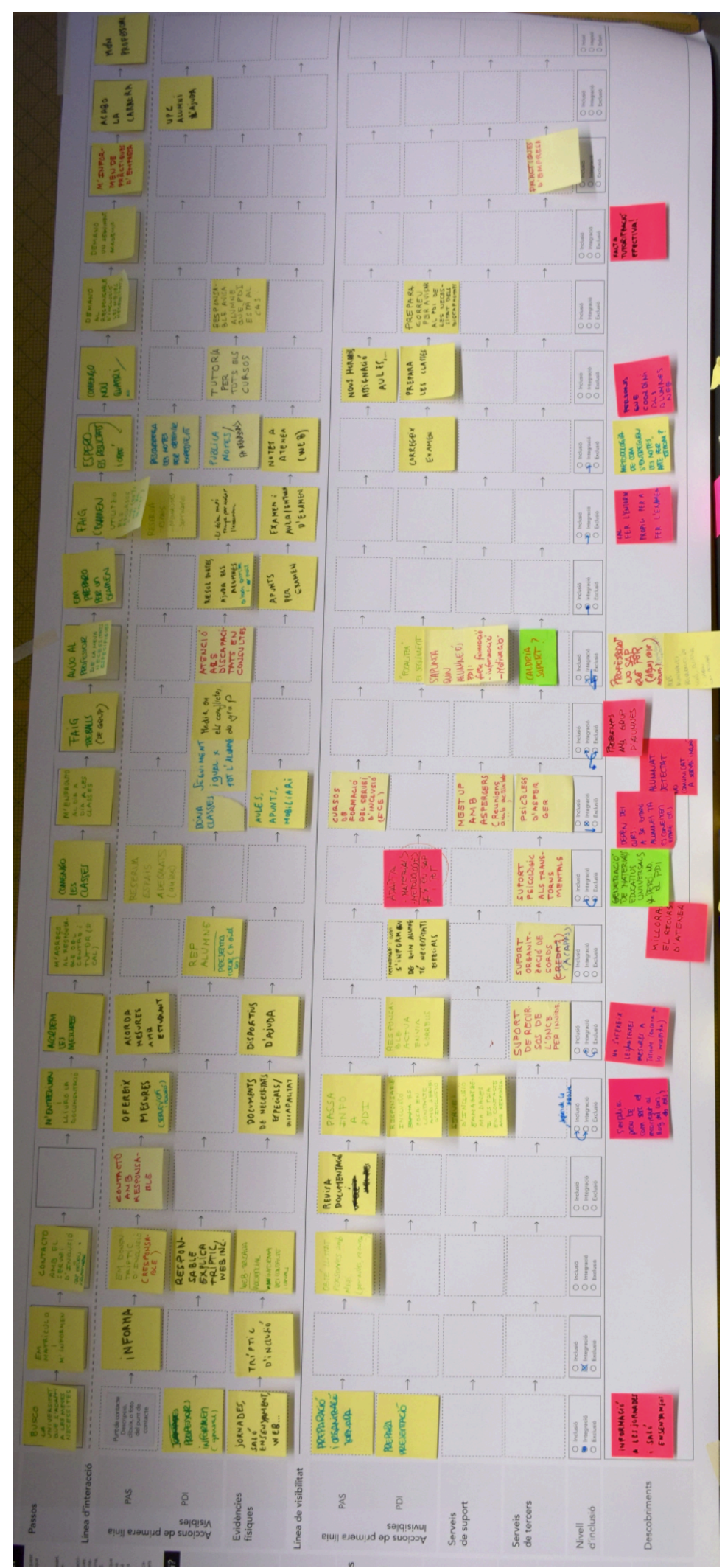

Figure A.2 Development of the Service Plan Model 


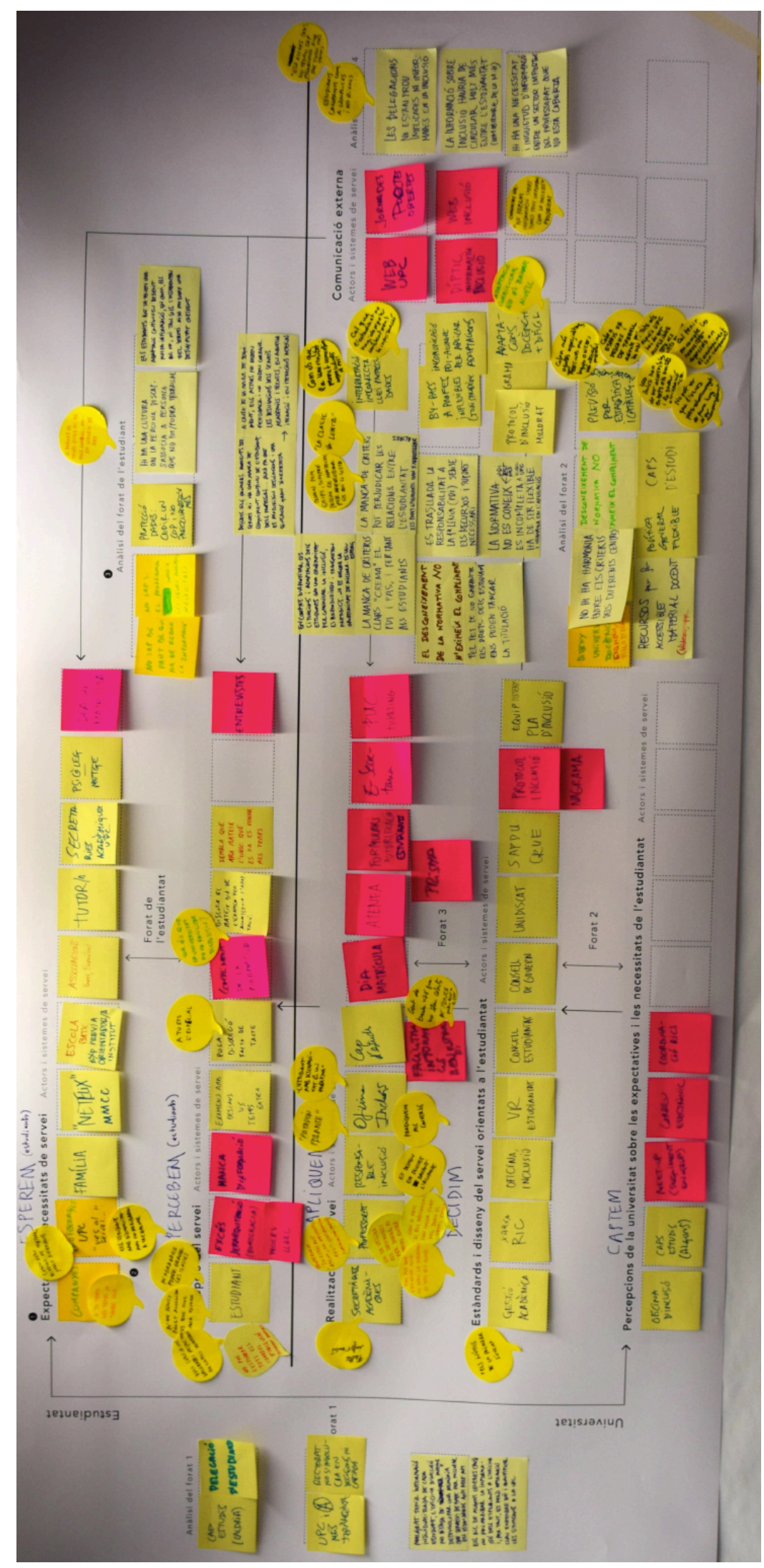

Figure A.3 Development of the Gaps Model 